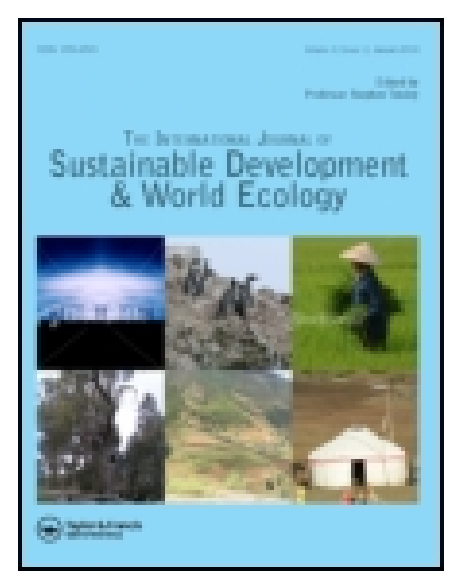

International J ournal of Sustainable Development \& World Ecology

Publication details, including instructions for authors and subscription information:

http:// www.tandfonline.com/loi/tsdw20

\title{
Ecosystem approach to management of the Bohai Sea region: towards sustainable development of coastal urban areas
}

J un Qiu , Zhiguo Gao \& J ingzhu Zhao

Published online: 08 Apr 2010.

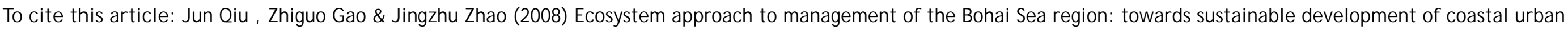
areas, International J ournal of Sustainable Development \& World Ecology, 15:S1, 25S-34S, DOI: 10.3843/ SusDev. 15.4:4

To link to this article: http://dx.doi.org/ 10.3843/ SusDev. 15.4:4

\section{PLEASE SCROLL DOWN FOR ARTICLE}

Taylor \& Francis makes every effort to ensure the accuracy of all the information (the "Content") contained in the publications on our platform. However, Taylor \& Francis, our agents, and our licensors make no representations or warranties whatsoever as to the accuracy, completeness, or suitability for any

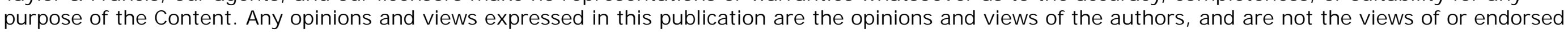

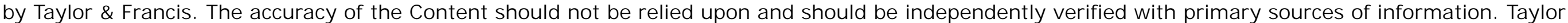

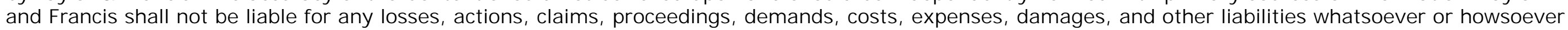
caused arising directly or indirectly in connection with, in relation to or arising out of the use of the Content.

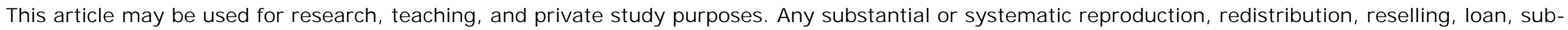
licensing, systematic supply, or distribution in any form to anyone is expressly forbidden. Terms \& Conditions of access and use can be found at http:// www.tandfonline.com/page/terms-and-conditions 


\title{
Ecosystem approach to management of the Bohai Sea region: towards sustainable development of coastal urban areas
}

\author{
Jun Qiu ${ }^{1,2}$, Zhiguo Gao and Jingzhu Zhao ${ }^{1,3}$ \\ ${ }^{1}$ State Key Laboratory of Urban and Regional Ecology, Research Center of Eco-environmental \\ Sciences, Chinese Academy of Sciences, Beijing, China \\ ${ }^{2}$ Chinese Institute for Marine Affairs, State Oceanic Administration, Beijing, China \\ ${ }^{3}$ Institute of Urban Environment, Chinese Academy of Sciences, Xiamen, China \\ Key words: Ecosystem approach, coastal urban areas, management, marine environmental monitoring, \\ public ocean awareness
}

\begin{abstract}
SUMMARY
Coastal urban areas (CUAs) comprise large population centres where many social and economic activities take place. Development of CUAs in the Bohai Sea region has had great impacts on the marine and coastal ecosystems, resulting in ecosystem degradation and a decline in ecosystem resources, thus undermining the basis for sustainable CUA development in the region. The current management system, with problems such as jurisdictional fragmentation and poor coordination among different sectors, has failed to coordinate CUA development with ecosystem conservation. To overcome these problems, we suggest an ecosystem approach for management of the Bohai Sea region. Some critical issues involved in applying an ecosystem approach in the region are addressed: (1) promoting cross-sectoral cooperation; (2) creating a master plan for sustainable development of the region; (3) improving marine environmental monitoring; and (4) strengthening public ocean awareness.
\end{abstract}

\section{INTRODUCTION}

Coastal areas attract human settlement because of their beauty, accessibility and numerous ecosystem resources (Martínez et al. 2007) and represent the most active and concentrated areas of socioeconomic activity around the globe. A large percentage (more than $41 \%$ ) of the world population lives on or near the coast (Angelidis and Economou 2004; United Nations 2005). Furthermore, populations in coastal areas will continue to grow,

especially in less developed regions (Li 2003). In fact, the population of coastal cities has doubled in the last 20 years, whereas the average city population has increased by approximately one-third (UNESCO 2000). Population growth and migration have driven coastal urbanisation around the world (Kullenberg 2001). Coastal urbanisation in China is also prominent. Approximately $40 \%$ of the population and $50 \%$ of the GDP are distributed in

Correspondence: Jun Qiu, Chinese Institute for Marine Affairs, State Oceanic Administration, Beijing 100860, China. Email: jqiu@cima.gov.cn 
areas within $200 \mathrm{~km}$ of the coastline, mostly concentrated in coastal cities. Moreover, the trend for concentration of people and economic activities in megacities is still strong.

Coastal cities around the world are rapidly degrading ecosystems and causing ecosystem simplification, and the pollution brought by urbanisation has damaged marine ecosystems and placed excessive demands on seafood, which has stimulated overfishing, resulting in exhaustion of fishery resources (Connell 2001; Kullenberg 2001; King and Adee 2002; Li 2003; Pew Oceans Commission 2003). In China, monitoring indicates that rapid development of coastal urban areas (CUAs) has been achieved at the cost of coastal ecosystem degradation and a decrease in ecosystem resources. Moreover, severe marine pollution near CUAs is ongoing (State Oceanic Administration 1992-2007). On the other hand, coastal ecosystem degeneration and the frequent occurrence of marine environmental hazards such as red tides, seawater intrusion and coastal erosion are undermining the basis for sustainable CUA development. The ecological reasons for the original location of cities in coastal zones are under serious threat (State Oceanic Administration 1992-2007). The region around the Bohai Sea is one of China's three largest coastal urban agglomerations, and the Bohai Sea has the worst pollution.

Healthy marine ecosystems are essential for CUA development. There is an ongoing search for a better marine management framework that allows CUA development while maintaining marine ecosystem health and resources. A consensus has been reached to carry out integrated marine management so as to effectively coordinate the relations between CUAs and marine ecosystems, and to help realise the goal of CUA sustainable development (UNESCO 2000; United Nations 2005). At the Earth Summit in Rio de Janeiro, Brazil in 1992, it was proposed that an ecosystem approach should be adopted for integrated marine management Many coastal countries such as Australia, Canada, and the United States, as well as the European Union, have explicitly incorporated an ecosystem approach into their national marine policies (US Commission on Ocean Policy 2004; Foster et al. 2005; European Commission 2006). There is a need to incorporate an ecosystem approach into China's marine management. The Bohai Sea region was chosen as a typical area to study the implementation of an ecosystem approach.

\section{BACKGROUND}

\section{The Bohai Sea region}

The area in which an ecosystem approach is applied can be defined on a number of geographic scales, depending on natural characteristics, socioeconomic factors, administrative boundaries, and especially the problems or issues being addressed (Secretary-General of the United Nations 2006). The Bohai Sea region is defined in this paper as an area encompassing the Bohai Sea and the terrestrial area of 13 coastal municipalities (Figure 1), which cover the following:

- All seaside cities around the Bohai Sea;

- Most human activities that impact marine ecosystems in the region;

- Most interactions between the marine and terrestrial ecosystems;

- Most of terrestrial areas within $100 \mathrm{~km}$ of the coastline, which is typically used to delimit the landward scope of the coastal zone (Cicin-Sain 2002; Small and Nicholls 2003; Martínez et al. 2007)

This definition also makes it easier to obtain the necessary information from local governments.

\section{The Bohai Sea}

The Bohai Sea is one of the ten largest inland seas in the world, with an area of approximately $77,000 \mathrm{~km}^{2}$ and a mean depth of $18 \mathrm{~m}$. It has a continental coastline of $3024 \mathrm{~km}$ in length. The Bohai Strait in the east is the only passage connecting the Bohai Sea to the outer Yellow Sea. More than 40

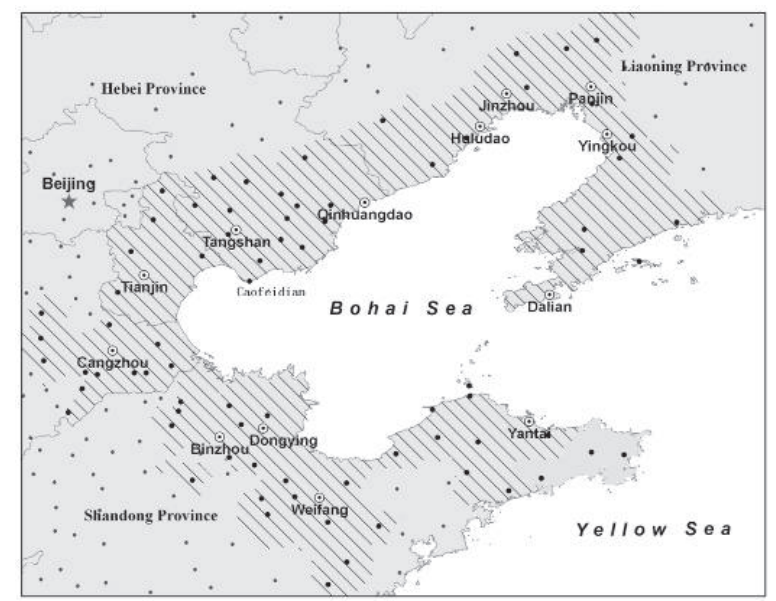

Figure 1 Location of the Bohai Sea region 
rivers, including the Yellow River, flow into the Bohai Sea. The Bohai Sea is relatively an independent part of the Yellow Sea-Bohai Sea Large Marine Ecosystem. Mainly influenced by human activities in CUAs, the Bohai Sea is seriously polluted and the ecosystem has significantly deteriorated.

Urbanisation in the Bohai Sea region

The Bohai Sea Region is highly urbanised. There are 70 cities within the region, 13 of which have a population of more than 500,000, and five megacities with more than 1 million people, namely, Dalian, Tangshan, Tianjin, Weifang and Yantai. There are three large ports, Tianjin, Dalian and Qinhuangdao, with a handling capacity of over 100 million tons each. In the past decade, the speed of urbanisation in the region has increased noticeably. The annual growth in population, construction area and power consumption in 13 large cities between 1995-2005 was remarkably higher than that between 1985-1995 (Table 1). A trend whereby economic activities concentrate towards the coastal cities is also noticeable. The gross production of the 13 municipalities as a proportion of that of the provinces to which they belong increased from $20.7 \%$ in 1995 to $29.8 \%$ in 2005 .

\section{Urbanisation impacts on marine ecosystems}

Numerous studies have shown that human modification of the natural landscape has a direct and significant effect on nearshore marine systems (Harvell et al. 1999). Development of CUAs has caused very significant impacts on the marine ecosystem of the Bohai Sea. Major manifestations include the deterioration of seawater quality due to the large amount of sewage discharged and a reduction in habitat complexity in the coastal zone due to the construction of urban infrastructure. Much of the coastal wetland has been reclaimed for mariculture, and overfishing is resulting in exhaustion of fishery resources.

Approximately 20-30\% of land-based pollutants discharged into the Bohai Sea originate from sewage outlets in the coastal cities. The total amount of sewage discharge increased from $1.8 \times 10^{8} \mathrm{~m}^{3} /$ year in the 1970 s to about $4 \times 10^{8} \mathrm{~m}^{3} /$ year in the $1990 \mathrm{~s}$ and at the start of the 21st century (Wang and Li 2006). This continuous increase in land-based pollutants has led to deterioration in water quality in nearshore sea areas, with approximately $25 \%$ of sea areas failing to meet Class I limits of the national seawater quality standard (Figure 2). Discharge of pollutants has also led to marine ecosystem degradation. Ecological monitoring between 2003 and 2006 revealed that most ecosystems in nearshore sea areas were unhealthy (State Oceanic Administration 1992-2007).

With the growth of urban population and the sprawl of CUAs, the demand for land for urban development is increasing, resulting in rapid growth of land reclamation from the sea. According to incomplete statistics, by 2003 , the area of land reclaimed from the sea for construction amounted to $3000 \mathrm{~km}^{2}$, with a sea wall of nearly $2600 \mathrm{~km}$. In recent years, the speed of land reclamation from the sea has increased due to the rocketing prices of urban housing and construction of industrial parks in the coastal cities. For example, in the first phase of the land reclamation project in Caofeidian Industrial Park in Tangshan, $12 \mathrm{~km}^{2}$ has been reclaimed from the sea and an additional $200 \mathrm{~km}^{2}$ is

Table 1 Some indicators of urbanisation in the Bohai Sea region

\begin{tabular}{lrrrrr}
\hline & & & & \multicolumn{2}{c}{ Average annual growth rate (\%) } \\
\cline { 5 - 6 } Parameter & 1985 & 1995 & 2005 & $1985-1995$ & $1995-2005$ \\
\hline Population $(10,000)$ & 1317 & 1783 & 2269 & 1.53 & 2.76 \\
Number of megacities & 4 & 5 & 5 & - & - \\
Construction area $\left(\mathrm{km}^{2}\right)$ & 755 & 1209 & 1797 & 2.38 & 4.43 \\
Power consumption $(100$ million $\mathrm{kWh})$ & 182 & 516 & 1216 & 5.33 & 9.94 \\
Water consumption (100 million t) & 82028 & 220752 & 215097 & 5.07 & 0 \\
Port handling capacity (10,000 t) & 12185 & 25207 & 88000 & 7.5 & 13.4 \\
Regional GDP compared to the four & - & 20.7 & 29.8 & - & - \\
coastal provinces involved (\%) & & & & & \\
\hline
\end{tabular}




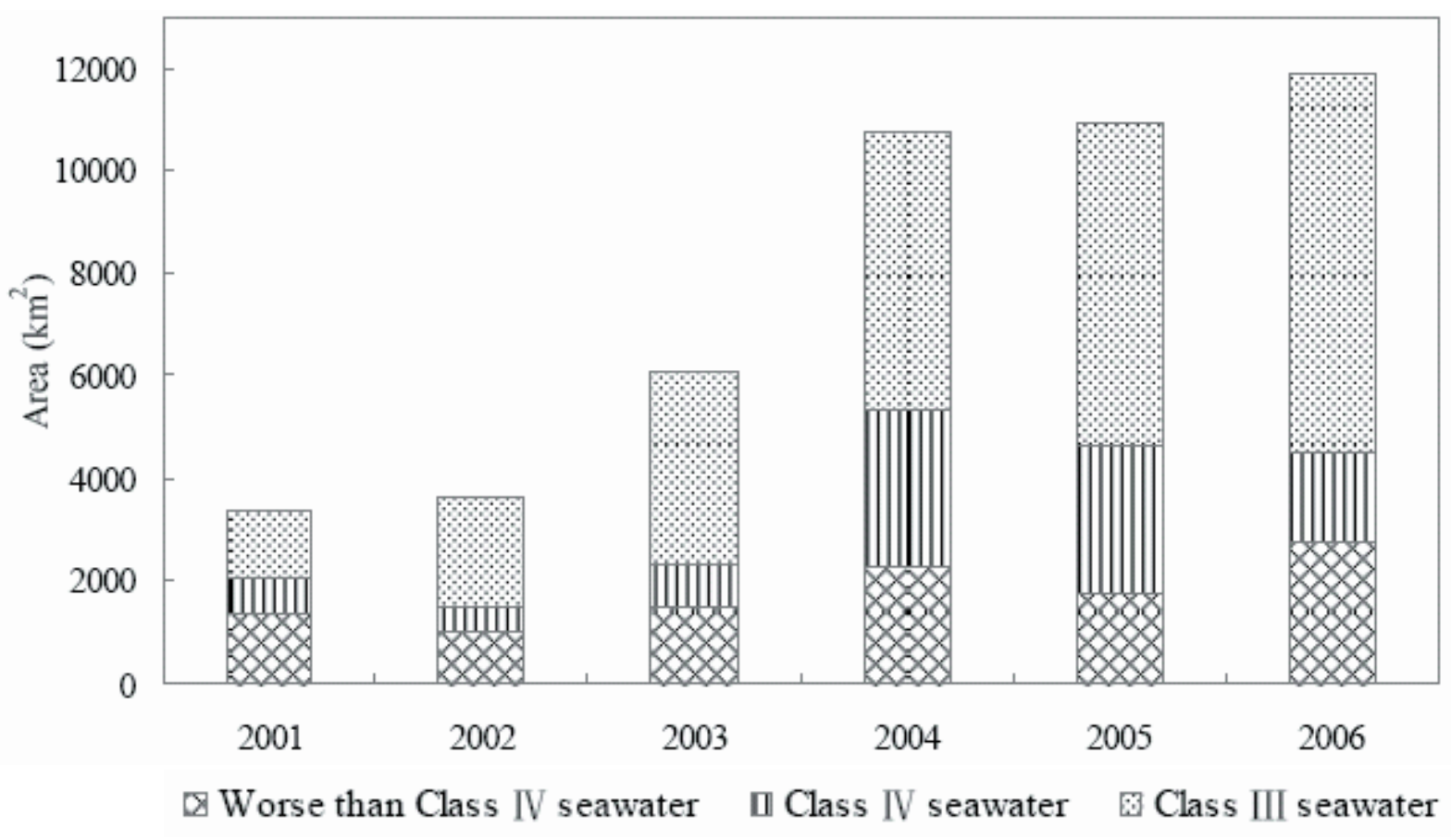

Figure 2 Sea area polluted to varying degrees, 2001-2006

Notes: Class III seawater, waters meet Class III water quality standards of China (GB3097-1997).

Class IV seawater, waters meet Class IV water quality standards of China (GB3097-1997).

Worse than Class IV seawater, waters with quality worse than Class IV standards of China (GB3097-1997)

planned for reclamation for the New Coastal District of Tianjin. Besides construction, approximately $6000 \mathrm{~km}^{2}$ of coastal wetland has been reclaimed for mariculture, making the Bohai Sea a major area of mariculture in China (45\%). Land reclamation from the sea over a large area can result in loss of marine habitats, deterioration of the seawater quality, and a decline in marine biodiversity (Harvell et al. 1999; Gu et al. 2003).

Because of overfishing and pollution, fishery resources are being exhausted in the Bohai Sea (Hao et al. 2001). The productivity of fish stocks decreased by $90 \%$ from the early 1980 s to the late 1990s. The proportion of high-quality fish species declined rapidly in the past several decades, while the proportion of low-quality species increased (Cheng 2004).

\section{Environmental deterioration undermines CUA development}

Sustainable CUA development strongly depends on sustainable utilisation of marine resources, as well as conservation of marine ecosystems. Undoubtedly, deterioration of the marine environment undermines the basis for sustainable CUA development. Seawater pollution accelerates the decline in fish stocks and harms the development of the fishing industry, and results in frequent red tides, which threaten public health and mariculture production. Since 2000, the number of red tides has increased remarkably (Figure 3). From 2000-2006 alone, the total number of red tides observed increased to 84 (State Oceanic Administration 1992-2007).

Seawater intrusion has become a major environmental/geological hazard in the study area. Overexploitation of groundwater to meet the increasing demand for freshwater in cities is a primary reason for seawater intrusion. Cities such as Dalian, Qinhuangdao and Tianjin are facing this problem. In 2005, intrusion into Dalian reached $5.6 \mathrm{~km}$ and the area affected by seawater intrusion in the region is more than $2674 \mathrm{~km}^{2}$ (Sun et al. 2006).

Destruction of vegetation in the coastal zone, sand mining and coastal engineering can alter marine hydrodynamic conditions and hence aggravate coastal erosion. The coastline in Yingkou, Yantai and Huludao has suffered serious erosion, some at $4 \mathrm{~m}$ /year (State Oceanic Administration 1992-2007). Coastal erosion has greatly harmed CUA development (Li et al. 2004). 


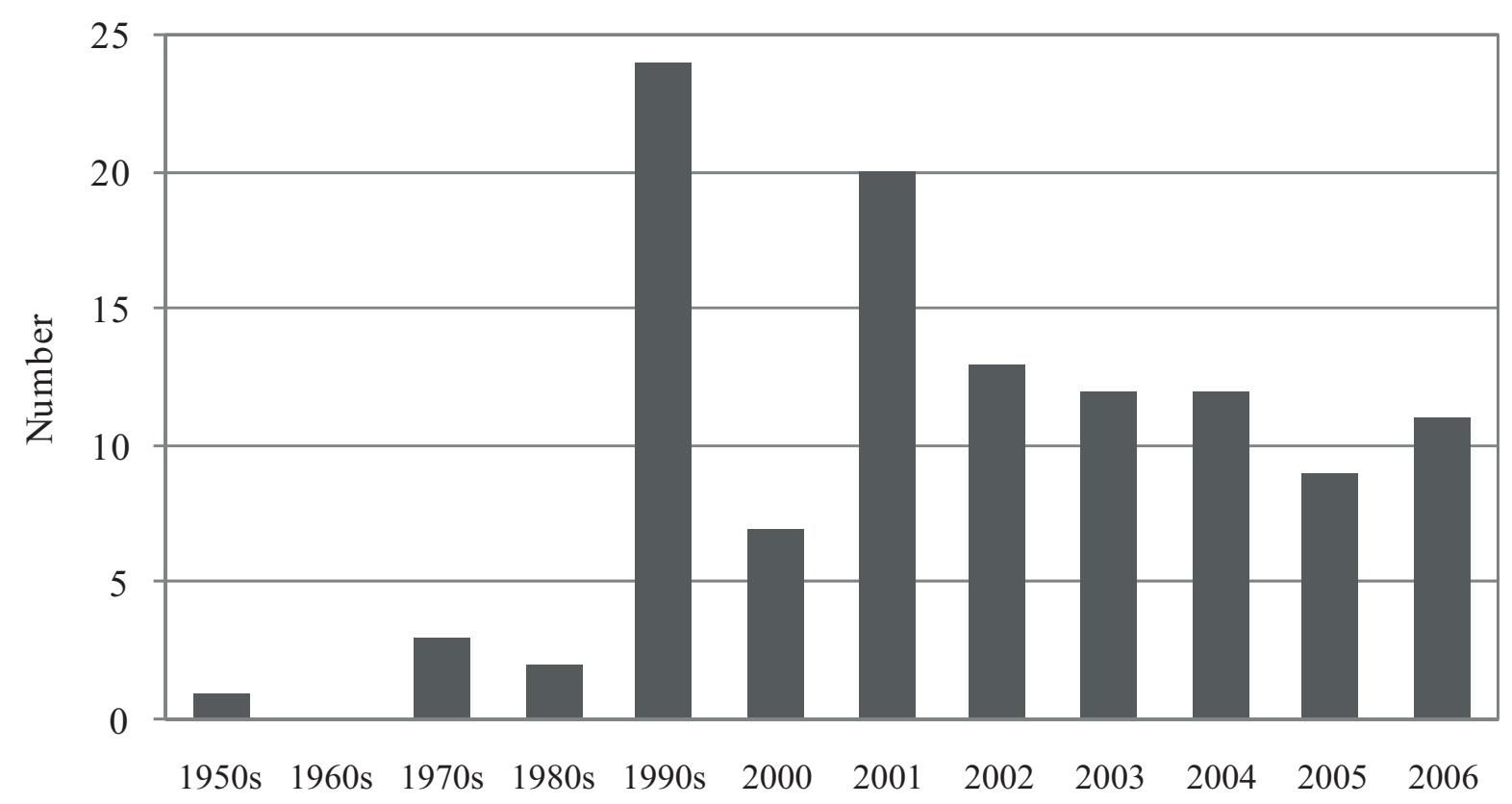

Figure 3 Number of red tides recorded in the Bohai Sea from 1950 onwards

Further CUA development is highly dependent on the Bohai Sea

The Bohai Sea plays an important supporting role in the social and economic development of CUAs. This is reflected in the development plans of both the state and the coastal provinces. According to development plans of coastal provinces around the Bohai Sea, the oceanfront will be a key development region in the near feature. Tianjin will focus on the construction of the New Coastal District, and plans to expand to become an international port and an economic centre in northern China. Hebei Province will focus on construction of the Caofeidian Industrial Park, a large world-level steel production base. Liaoning Province will build a coastal industrial zone around the coastal cities of Dalian, Yingkou, Panjin Jinzhou and Huludao. Shandong Province will also emphasise the development of its coastal region in the future. The constructions of Tianjin's New Coastal District and Caofeidian Industrial Park have been included in China's overall development strategy. Undoubtedly, the Bohai Sea region will become one of the most important development areas in China in the near future. This will bring new challenges for pollution control and restoration of the marine ecosystem.

\section{FAILURE OF CURRENT MARINE AND COASTAL MANAGEMENT}

For conservation of marine ecosystems and sustainable utilisation of marine resources, a series of laws have been enacted in China. Systems have also been established to charge for discharging pollutants into the sea and for marine function zoning. Furthermore, since 2000 the Chinese Government has spent a large amount of money to implement the Blue Sea Action Plan to control land-based pollution. However, these laws, systems and projects cannot stop the deterioration of the Bohai Sea marine ecosystem.

\section{Jurisdictional fragmentation}

The essential characteristic of the current marine and coastal management system in China is sectorby-sector management, which means that each resource or sea use typically falls under the jurisdiction of a different administrative department operating under a different legislative framework. There are several departments with jurisdiction over marine affairs, including the State Oceanic Administration, the State Environmental Protection Administration, the Ministry of Communications, the Ministry of Agriculture, the State 
Administration of Forestry, the Ministry of Construction, and the Ministry of Water Resources. Each department has authority over one or more aspects of marine affairs, and acts within its own terms of reference, without close cooperation with other departments. This leads to jurisdictional fragmentation.

Jurisdictional fragmentation also arises from administrative division. All local governments exercise actions within their own administrative region. With regard to the control of land-based pollutants, each city focuses only on the compliance status of its own wastewater discharge, ignoring the fact that the total quantity of pollutants discharged by all cities actually exceeds the maximum environmental capacity of the Bohai Sea.

In addition, the current management systems for sea areas and land areas differ. A marine function zoning system has been established in China for multi-use of sea areas. This system is only applicable to the area seaward from the coastline, while the development and use of areas landward from the coastline are subject to the land-use planning system. The two systems are under the jurisdiction of different departments, resulting in management segmentation between land areas and sea areas.

\section{Jurisdictional overlap}

Sector-by-sector management results in not only jurisdictional fragmentation, but also jurisdictional overlap in some fields. For example, the State Forestry Administration has jurisdiction over coastal wetlands under the Wildlife Protection Act, and the State Oceanic Administration also has jurisdiction over coastal wetlands in tideland under the Marine Environmental Protection Act and the Sea Use Management Act. Where jurisdiction overlap exists, it is difficult to coordinate the work of various sectors (Lau 2005). When there are sectoral interests, the relevant sectors will compete to exercise their jurisdiction, which may lead to conflict.

\section{Poor coordination}

In sector-by-sector management systems, coordination and cooperation among different sectors are indispensable. Current coordination is too poor to realise effective management (Yang 1997; Lu 2001). Taking sea area use as an example, as mentioned above, the marine function zoning system was established to facilitate overall arrangements for multiple uses of sea areas among various related sectors; however, the results were not satisfactory because of poor coordination among different sectors. Multi-use conflicts are still serious in areas of the Bohai Sea. For example, over $80 \%$ of the sewage outlets for coastal cities are located in mariculture, tourism or marine protection areas, where clean seawater is required.

Moreover, coordination among different parts of the same sector is also poor in some fields. To control land-based pollution, which is the main cause of environmental degradation in the Bohai Sea, more than 65 wastewater treatment plants were built or expanded in recent years to yield a total capacity exceeding $5 \times 10^{6} \mathrm{~m}^{3} /$ day in the Bohai Sea region. However, more than $40 \%$ of this capacity is not being used because of the absence of collection systems for the treatment facilities (Wang and Xia 2006)

\section{Insufficient knowledge of coastal ecosystems}

The coastal urban ecosystem is a highly developed and very complicated economic-social-natural system. Scientific decision-making strongly depends on sufficient knowledge of the ecosystems involved, but there is a wide gap between current understanding and the knowledge required for such scientific decision-making (Chen and Wang 2003). For example, although monitoring has been conducted for many years, the total quantity of pollutants discharged annually into the Bohai Sea is still not clear. Statistical data reported by the State Environmental Protection Administration are significantly different to those reported by the Ministry of Water Resources and the Ministry of Construction (Wang and Xia 2006).

\section{Poor public awareness}

Public awareness of the ocean in China is still weak (Ma 2001; Liu et al. 2005). The sea is only considered as a source of resources and a site for waste disposal. Marine ecosystem protection has not attracted attention for a long period of time. Poor public awareness is an obstacle to effective public involvement in marine ecosystem management. Insufficient public participation hampers the exchange of viewpoints between officials and local 
residents and can weaken the management capacity of the government (Shi et al. 2001).

\section{ECOSYSTEM APPROACH DEFINITION AND PRINCIPLES}

After the 1992 Earth Summit, in which the ecosystem approach was proposed, the concep became popular all around the world. Many terminologies and relevant definitions also emerged (Arkema et al. 2006). According to the 2000 Convention on Biological Diversity, 'The ecosystem approach is a strategy for the integrated management of land, water and living resources that promotes conservation and sustainable use in an equitable way,' as well as 'a strategy . . . to reach balance between . . . conservation, sustainable use, and fair and equitable sharing of the benefits arising from the utilization of genetic resources (Garcia et al. 2003). Ecosystems approach management (EAM) is defined by the US National Oceanic and Atmospheric Administration as a comprehensive framework for marine and coastal resource decision-making. In contrast to management of individual species or single issues, EAM considers a wider range of relevant ecological, environmental, and human factors that influence societal choices regarding resource use (Murawski 2007). There are many similar definitions of the ecosystem approach Witherell et al. 2000; Arkema et al. 2006; Murawski 2007) and it is not necessary to list them all here. However, all the definitions share the following elements:

1. Human factors. While emphasising that humans are an important component of the ecosystem, it also focuses on human use of available resources.

2. Ecosystem health. This emphasises the need to maintain the integrity and health of the ecosystem to realise the provision of $\mathrm{eco}^{-}$ system resources.

3. Integrated management. EAM is crosssectoral, which means management plans are comprehensive, and all factors, ecological, economic, social and institutional, must be comprehensively considered.

Principles and guidelines for the development of EAM have been identified by a diverse set of sectoral interests in both terrestrial settings and coastal and oceanic environments (Slocombe 1998; LaMare 2005; Murawski 2007). The Convention on Biodiversity put forward 12 principles of EAM, and the US Commission on Ocean Policy and the Pew Oceans Commission identified nine principles for the implementation of ecosystem approach. All these different understandings include the following four core issues:

1. Ecological management unit. An ecosystem approach should be implemented in specific areas that are defined by the ecosystem rather than by political boundaries.

2. Comprehensive perspective. A long-term and comprehensive management goal is required. This must be consistent with the principles of sustainable development; it must consider the interests of relevant stakeholders, including supporting economic development, maintaining ecosystem health and meeting social demands.

3. Precautionary and adaptive management. An ecosystem approach recognises that every human activity may cause uncertain results. Sufficient preplanning must be carried out to allow for likely uncertainties that may arise during the management process. The effectiveness of measures should be reviewed through regular monitoring and assessment to identify and correct any deviations from the goal in a timely manner.

4. Stakeholder participation. The approach encourages stakeholders to cooperate and participate in management actions.

\section{AN ECOSYSTEM APPROACH TO MANAGEMENT OF THE BOHAI SEA REGION}

\section{Promoting cross-sectoral cooperation}

A sector-by-sector approach is not an efficient way to manage complicated marine and coastal ecosystems affected by both natural and human factors. For example, river and riverbank improvement projects carried out by the construction sector may lead to simplification of river habitats, which is unfavourable for the breeding of migratory fish and birds. This will affect fish stock recruitment and 
thus trigger responses from corresponding fishery management authorities. Cross-sectoral cooperation is essential to solve such issues and should be implemented in both individual cities and on a regional basis.

To promote cross-sectoral cooperation in an individual city, it is necessary to reform the decision-making mechanism and establish a new and open platform that allows all relevant departments to participate in the entire decision-making process. Such a platform helps decision-makers to obtain more information and make more informed decisions. The practice of integrated coastal management in other coastal cities in China indicates that the success of cross-sectoral cooperation relies strongly on coordination with high-level local government officials (Qiu et al. 2008).

Management of the Bohai Sea region involves the jurisdictions of 13 coastal municipalities in three provinces, one province-level municipality, and several ministries and commissions under the State Council. It is difficult to coordinate these bodies on integrated management issues, as they are at the same administrative level. Therefore, on a regional basis, it is necessary to establish a highlevel coordination mechanism for regional development to address major issues that cannot be solved by local governments. This mechanism should be led by the State Commission of Development and Reform, with participation of all coastal provinces and relevant departments.

\section{Identifying a sustainable development plan}

Each municipality focuses on its own development plan without a regional perspective in the current management system. With a lack of regional coordination, deleterious competition among municipalities is unavoidable. All coastal municipalities highlight harbour development in their develop ment strategies. Besides the existing 40 ports along the Bohai Sea coast, a large port with a handling capacity of over 500 million tons is planned at Caofeidian in Tangshan. In addition, Cangzhou, Yantai and Yingkou also plan to build their own large ports with handling capacity of over 100 million tons. If all these ports are constructed as planned, there will be seven large ports in the region. In terms of industrial structure, most of these coastal municipalities focus on heavy chemical industries on the waterfront

It is necessary to develop a sustainable regional development plan to solve such coordination failures. In such a plan, the overall social, economic and ecological goal should be clearly defined; the complicated relations between the Bohai Sea and the adjacent land area must be considered; exploitation and utilisation of marine resources and protection of the marine ecosystem must be taken into consideration; and relations among the developments of Tianjin New Coastal District, Caofeidian Industrial Park, the Coastal Economic Zone and the coastal urban agglomeration in Shandong Province must be addressed.

\section{Improving marine environmental monitoring}

Monitoring is essential to assess the health of marine and coastal ecosystems and detect dynamic changes. More than any other measure, monitoring provides accountability for management actions (US Commission on Ocean Policy 2004). Ongoing monitoring mainly focuses on basic hydrology parameters, water quality and bottom sediments, and the monitored area is limited to some key sea areas. It cannot meet the requirements of an ecosystem approach in terms of spatial density, temporal frequency or monitoring parameters. A comprehensive monitoring network providing enough information for informed decisions is required. Thus, existing monitoring systems, which are scattered in various departments, should be integrated and more monitoring points should be identified.

\section{Strengthening awareness}

The public needs to understand the importance of the ocean for their lives and to realise how individual actions can impact the marine environment. In particular, local residents and government officials should realise that the marine ecosystem is a key component of the coastal urban ecosystem, and a healthy marine ecosystem is essential to maintain the urban environment. Public awareness will encourage citizens to protect marine ecosystems and hence will improve public participation in local marine ecosystem management. In traditional management systems, the decision-making process 
invariably only involves special groups such as government officials and certain experts (Shi et al. 2001). Within the framework of ecosystem-based approach, governments should provide more opportunities for the participation of local residents.

\section{ACKNOWLEDGEMENTS}

This study was supported by the National Natural Science Foundation of China (70325002) and the Chinese Academy of Sciences (KZCX2-YW-422).

\section{REFERENCES}

Angelidis M and Economou A. Environmental protection of coastal urban areas in the European Union. International Conference: Future Vision and Challenges for Urban Development. Cairo, Egypt; 2004

Arkema K, Abramson S and Dewsbury B. Marine ecosystem-based management: from characterization to implementation. Frontiers in Ecology and the Environment 2006;4:525-32

Chen $\mathrm{G}$ and Wang Y. Some issues in integrated coastal management. Marine Science Bulletin 2003;22: 39-44 (In Chinese)

Cheng J. Ecological Environment and Community in the Offshore Waters of the Yellow and Bohai Seas. Qingdao: Ocean University of China Press; 2004 (In Chinese)

Cicin-Sain B. An overview of policy issues and options for improved regional ocean governance. In Cicin-Sain B and Ehler CB (eds), Workshop on Improving Regional Ocean Governance in the United States. Washington DC; 2002:1-22; unpublished

Connell SD. Urban structures as marine habitats: an experimental comparison of the composition and abundance of subtidal epibiota among pilings, pontoons and rocky reefs. Marine Environmental Research 2001;52:115-25

European Commission. Towards a Future Maritime Policy for the Union: A European Vision for the Oceans and Seas. Luxembourg: Office for Official Publications of the European Communities; 2006

Foster E, Haward M and Coffen-Somout S. Implementing integrated oceans management: Australia's southeast regional marine plan (SERMP) and Canada's Scotian shelf integrated management (ESSIM) initiative. Marine Policy 2005;29:391-405

Garcia SM, Zerbi A, Aliaume C, Do Chi T and Lasserre G. The Ecosystem Approach to Fisheries. Issues, Terminology, Principles, Institutional Foundations, Implementation and Outlook. Rome: FAO; 2003

$\mathrm{Gu}$ D, Zhao X and Xia D. A systemic analysis of the environmental pressure factors on the degradation of coastal wetlands in China. Acta Oceanologica Sinica 2003;25:78-85 (In Chinese)
Hao Y, Bao H and Xu Z. On sustainable utilization of fishery resources in the Bohai Sea. Marine Science 2001;21:52-4 (In Chinese)

Harvell CD, Kim K, Burkholder JM et al. Emerging marine diseases-climate links and anthropogenic factors. Science 1999;285:1505-10

King C and Adeel Z. Strategies for sustainable coastal management in Asia and the Pacific - perspectives from a regional initiative. Global Environmental Change 2002;12:139-42

Kullenberg G. Contributions of marine and coastal area research and observations towards sustainable development of large coastal cities. Ocean and Coastal Management 2001;44:283-91

LaMare K. Marine ecosystem-based management as a hierarchical control system. Marine Policy 2005;29: $57-68$

Lau M. Integrated coastal zone management in the People's Republic of China - an assessment of structural impacts on decision-making process. Ocean and Coastal Management 2005;48:115-9

Li H. Management of coastal mega-cities - a new challenge in the 21st century. Marine Policy 2003;27:333-7

Li P, Li P, Xu X, Du J and Liu L. Influence of human activities on the coastal disaster environment. Coastal Engineering 2004;23:45-9 (In Chinese)

Liu J, Jiang J and Huang S. A survey of college students' ocean awareness. Journal of Zhanjiang Ocean University 2005;25:143-7 (In Chinese)

$\mathrm{Lu}$ C. Discussion on integrated marine management. China Soft Science 2001;16:14-6 (In Chinese)

Ma J. Reflections on education for increasing the nation's marine awareness. Journal of Shanxi University of Finance and Economics 2001;23:1-4 (In Chinese)

Martínez ML, Intralawan A, Vázquez G, Pérez-Maqueo $\mathrm{O}$, Sutton $\mathrm{P}$ and Landgrave R. The coasts of our world: Ecological, economic and social importance. Ecological Economics 2007;63:254-72

Murawski SA. Ten myths concerning ecosystem approaches to marine resource management. Marine Policy 2007;31:681-90 
Pew Oceans Commission. America's Living Oceans: Charting a Course for Sea Change. Arlington, VA: Pew Oceans Commission; 2003

Qiu J, Zhao J, Deng H and Li M. Ecosystem-based marine management: Principles, practices and suggestions. Marine Environmental Science 2008 27:74-8

Secretary-General of the United Nations. Oceans and the law of the sea. In 61st Session of the General Assembly of the United Nations. New York: UN; 2006

Shi C, Hutchinson SM, Yu L and Xu S. Towards a sustainable coast: an integrated coastal zone management framework for Shanghai, People's Republic of China. Ocean and Coastal Management 2001; 44:411-27

Slocombe DS. Lessons from experience with ecosystem-based management. Landscape and Urban Planning 1998;40:31-9

Small C and Nicholls RJ. A global analysis of human settlement in coastal zones. Journal of Coastal Research 2003;19:584-99

State Oceanic Administration. Chinese Marine Environ ment Quality Bulletin. Beijing: State Oceanic Administration; 1992-2007 (In Chinese)

Sun X, Xu J, Yang O, Shi P, Zhong X, Zhang S, Pan T and Zhao C. Character and prevention strategies of sea (saline) water invasion in the circumBohai-Sea region. Geological Survey and Research 2006;29:203-11 (In Chinese)

US Commission on Ocean Policy. An Ocean Blueprin for the 21st Century. Washington DC: US Commission on Ocean Policy; 2004

UNESCO. IOC-SOA International Workshop on Coastal Megacities: Challenges of Growing Urbanisation of the World's Coastal Areas. HangZhou, 2000; unpublished

United Nations. Human Development Report. International Cooperation at a Crossroads: Aid, Trade and Security in an Unequal World. New York: UNDP; 2005

Wang X and Xia Q. General Plan for Environmental Protection in the Bohai Sea. Beijing: State Commission of Development and Reform of China; 2006 (In Chinese)

Wang XL and Li KO. Marine Environmental Capacity of Pollutants in the Bohai Sea. Beijing: Science Press; 2006 (In Chinese)

Witherell D, Pautzke C and Fluharty D. An ecosystem-based approach for Alaska groundfish fisheries. Journal of Marine Science 2000;57:771-7

Yang H. Discussion on the Bohai Sea management. China Soft Science 1997:12:119-22 (In Chinese) 